\title{
ANALISIS KEPUASAN PELANGGAN TERHADAP KUALITAS PELAYANAN DI PT RAMAJAYA COPIER
}

\author{
Sudrajad JS ${ }^{1}$ ), Nur Rahma Andayani²) \\ ${ }^{1}$ ) Prodi Administrasi Bisnis Terapan, Politeknik Negeri Batam, Batam,Indonesia, email: \\ wakajad@gmail.com \\ 2 ) Prodi Administrasi Bisnis Terapan, Politeknik Negeri Batam, Batam,Indonesia, email: \\ nunun@polibatam.ac.id
}

\begin{abstract}
Research on customer satisfaction analysis on service quality at PT Ramajaya Copier is to analyze and determine the extent of customer satisfaction with the services provided by PT Ramajaya Copier. This research was conducted to 93 PT Ramajaya Copier customers in Batam City using the Simple Random Sampling technique. Using the method of analysis of important performance analysis (IPA) of this study resulted in 4 (four) indicators of service satisfaction statements included in quadrant I, namely improving performance to be improved to meet customer expectations. The four indicators of the statement are: employees are polite and friendly to customers (2.61), customer convenience when coming to PT Ramajaya (2.69), the company serves regardless of customer background (2.61), the company tolerates delays payment to customers (2.61).
\end{abstract}

Keywords: Service Quality, Customer Satisfaction, Important Performance Analysis (IPA)

\begin{abstract}
Abstrak
Penelitian analisis kepuasan pelanggan terhadap kualitas pelayanan di PT Ramajaya Copier adalah untuk menganalisis dan mengetahui sejauh mana tingkat kepuasan pelanggan terhadap pelayanan yang diberikan oleh PT Ramajaya Copier. Penelitian ini dilakukan kepada 93 pelanggan PT Ramajaya Copier yang ada di Kota Batam dengan menggunakan teknik Simple Random Sampling. Menggunakan metode analisis important performance analysis (IPA) penelitian ini menghasilkan 4 (Empat) indikator pernyataan kepuasan pelayanan yang termasuk ke dalam kuadran I yaitu tingkatkan kinerja untuk diperbaiki guna memenuhi harapan pelanggan. Keempat indikator pernyataan tersebut adalah : karyawan bersikap sopan dan ramah kepada pelanggan (2,61), kenyamanan pelanggan saat datang ke PT Ramajaya $(2,69)$, perusahaan melayani tanpa memandang latar belakang pelanggan $(2,61)$, perusahaan memberikan toleransi terhadap keterlambatan pembayaran kepada pelanggan $(2,61)$.
\end{abstract}

Kata kunci: Kualitas Pelayanan, Kepuasan Pelanggan, Important Performance Analysis (IPA) 


\section{LATAR BELAKANG}

Kualitas pelayanan adalah seberapa jauh perbedaan antara harapan dan kenyataan para konsumen atas layanan yang mereka terima. Kualitas pelayanan dapat diketahui dengan membandingkan persepsi konsumen atas layanan yang benar-benar mereka terima dengan layanan sesungguhnya yang mereka harapkan. Kualitas pelayanan menjadi hal utama yang diperhatikan serius oleh perusahaan, yang melibatkan seluruh sumber daya yang dimiliki perusahaan. Definisi mutu jasa berpusat pada pemenuhan kebutuhan dan keinginan konsumen serta ketepatan penyampaian untuk mengimbangi harapan konsumen.

Kualitas Pelayanan merupakan suatu fenomena yang unik sebab dimensi dan indikatornya dapat berbeda diantara orangorang yang terlibat dalam pelayanan. Kualitas pelayanan menunjuk pada tingkat kesempurnaan pelayanan dalam memenuhi kebutuhan dan tuntuan setiap konsumen, terpenuhi tidaknya kebutuhan dan tuntuan pemakaian pelayanan. Dalam kualitas jasa/pelayanan terdapat 5 dimensi yaitu bukti fisik, kehandalan, daya tanggap, jaminan dan empati yang dipakai dalam mengukur kualitas pelayanan terhadap kepuasan atau ketidakpuasan konsumen suatu perusahaan.

PT. Ramajaya Copier adalah suatu Badan Usaha yang berbentuk Perseroan Terbatas (PT) penyedia jasa/pelayanan yang berdiri pada 4 Juni 2009, dengan Kantor Pusat di J1. Pramuka No. 11-12, Tanjunpinang, Kepulauan Riau (Kepri). Kantor cabang di Batam beralamat di Komp. Ruko Puri Loka, Blok D No. 12 A, Sei Panas, Kota Batam. Adanya pertumbuhan yang baik dan kondusif sebagai hasil dari pemerintah yang selalu mendukung pertumbuhan industri diberbagai sektor inilah yang pada akhirnya mendorong PT Ramajaya Copier menjadi mitra kepercayaan perusahaan - perusahaan di Batam maupun pemerintah

Bergerak di bidang jasa/pelayanan umum khususnya kegiatan usaha perdagangan barang dengan mesin photocopy sebagai produknya, PT Ramajaya
Copier mempunyai visi dan misi yakni berkomitmen untuk selalu memberikan pelayanan yang berkualitas dengan selalu memperhatikan jaminan pelayanan produk dalam bidang mesin photocopy. Diawal berdirinya tahun 2009, PT Ramajaya Copier memiliki pelanggan sebanyak 56. Tahun 2010 PT Ramajaya Copier mengalami peningkatan sehingga pelanggan bertambah dua kali lipat menjadi 110 perusahaan/instansi yang menggunakan jasa PT Ramajaya Copier.

Dalam perjalanannya PT Ramajaya Copier terus mengembangkan sayapnya sehingga mencapai puncak ditahun 2014 dengan costumer mencapai 198. Seiring perkembangan waktu, dan banyak pesaing yang bergerak dibidang mesin photocopy sehingga tahun 2016 sampai tahun 2018 PT Ramajaya Copier mengalami penurunan pelanggan seperti pada grafik di bawah ini:

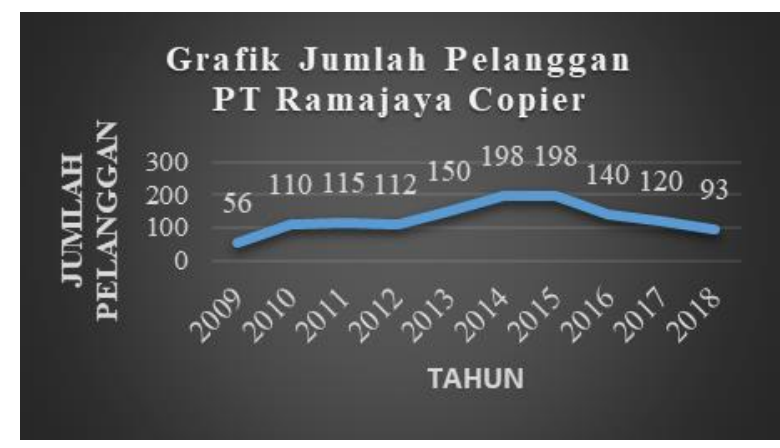

Gambar 1.1: Grafik Jumlah Pelanggan PT Ramajaya Copier Tahun 2009-2018 (Per Agustus) Sumber: PT Ramajaya Copier

Untuk itu peneliti ingin mengetahui mengapa terjadi penurunan pelanggan. Berdasarkan latar belakang dan pemikiran tersebut maka penulis mengadakan penelitian dengan judul: Analisis Kepuasan Costumer Terhadap Pelayanan di PT Ramajaya Copier

\section{Identifikasi dan Perumusan Masalah}

Adapun rumusan masalah penelitian analisis kepuasan pelanggan terhadap kualitas pelayanan di PT Ramajaya Copier adalah sejauh mana tingkat kepuasan pelanggan terhadap pelayanan yang diberikan oleh PT Ramajaya Copier. 


\section{Tujuan Penelitian}

Adapun tujuan penelitian analisis kepuasan pelanggan terhadap kualitas pelayanan di PT Ramajaya Copier adalah untuk menganalisis dan mengetahui sejauh mana tingkat kepuasan pelanggan terhadap pelayanan yang diberikan oleh PT Ramajaya Copier

\section{Manfaat Penelitian}

Sebagai bahan evaluasi kepada PT Ramajaya Copier khususnya pihak manajemen mengenai tingkat kepuasan yang dirasakan oleh pelanggan serta atribut yang mempengaruhi ketidakpuasan pelanggan agar dapat memperbaiki serta meningkatkan kualitas pelayanan PT Ramajaya Copier.

\section{Kepuasan Pelanggan}

Kepuasan adalah perasaan seseorang mengenai kesenangan atau hasil yang mengecewakan dari membandingkan penampilan produk yang telah disediakan (hasil) dalam yang berhubungan dengan harapan si pelanggan. Pelanggan adalah seorang individu atau kelompok yang memebeli produk fisik atau jasa dengan mempertimbangkan berbagai macam faktor seperti harga, kualitas, tempat, pelayanan dan lain sebagainya berdasarkan keputusan mereka sendiri.

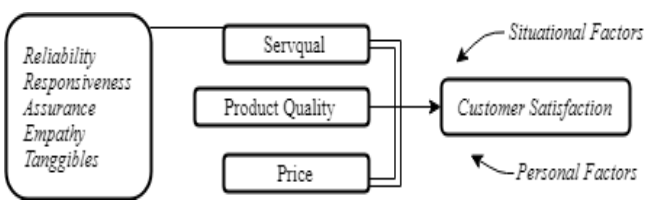

Gambar 2.1: Model Customer Satisfaction Sumber: Zeithaml dan Bitner (2000)

Kepuasan pelanggan adalah perasaan senang atau kecewa seseorang yang muncul setelah membandingkan kinerja (hasil) produk yang dipikirkan terhadap kinerja yang diharapkan Philip Kotler dan Kevin Lane Keller (2007). Faktor utama yang harus diperhatikan perusahaan dalam menentukan tingkat kepuasan pelanggan yaitu: Kualitas produk, Kualitas pelayanan, Emosional, Harga, Biaya.

\section{Kualitas Pelayanan}

Kualitas merupakan Suatu kondisi dinamis yang berhubungan dengan produk, jasa, manusia, proses dan lingkungan yang memenuhi atau melebihi harapan. Kualitas pelayanan adalah seberapa jauh perbedaan antara harapan dan kenyataan para konsumen atas layanan yang mereka terima.

Kualitas pelayanan dapat diketahui dengan membandingkan persepsi konsumen atas layanan yang benar-benar mereka terima dengan layanan sesungguhnya yang mereka harapkan. Dimensi pokok yang dapat digunakan untuk mengukur kualitas pelayanan, yaitu: Bukti Fisik, Keandalan, Daya Tanggap, Jaminan, Empati.

\section{Importance-Performance Analysis}

(IPA) merupakan metode Analysis diperkenalkan pertama kali oleh Martilla \& James (1977) dengan tujuan untuk mengukur hubungan antara persepsi konsumen dan prioritas peningkatan kualitas produk/jasa yang dikenal pula sebagai quadrand analysis. IPA mempunyai fungsi untuk menampilkan insformasi berkaitan dengan faktor pelayanan yang menurut konsumen sangat mempengaruhi kepuasan dan loyalitas konsumen tersebut, dan faktor - faktor pelayanan yang perlu ditingkatkan karena kondisi saat ini belum memuaskan Fadhillah, (2012).

IPA secara konsep merupakan suatu model multi atribut dengan menggabungkan pengukuran faktor tingkat kepentingan dan tingkat kepuasan dalam kuadran yang memudahkan penjelasan data dan mendapatkan usulan praktis. Kuadran IPA dibagi menjadi 4 kuadran yakni sebagai berikut:

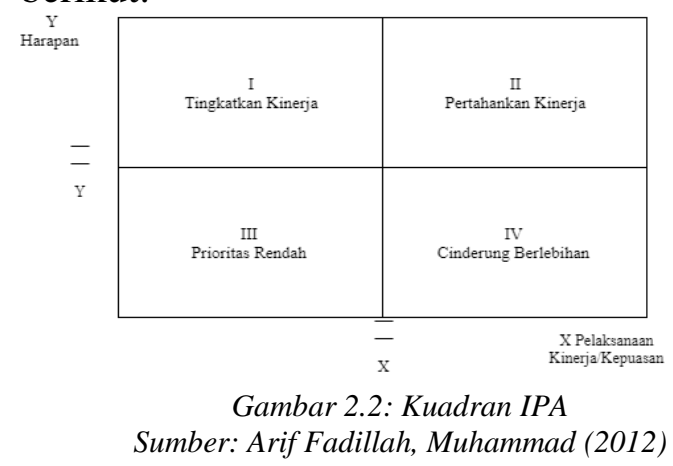




\section{Kerangka Penelitian}

Kerangka pemikiran dalam penelitian ini dibuat untuk mempermudah pemahaman terhadap penelitian yang dilakukan. Kerangka pemikiran merupakan model konseptual tentang bagaimana teori berhubungan dengan faktor yang telah diidentifikasi sebagai masalah penting. Kerangka pemikiran tersebut:

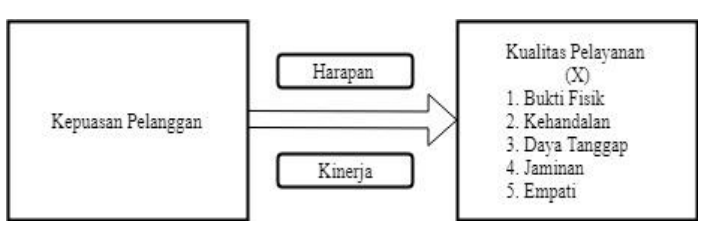

Gambar 2.3: Kerangka Pemikiran Sumber: Nani, Supardi (2014)

\section{Hipotesis Penelitian}

Tingkat kepuasan pelanggan terhadap pelayanan yang diberikan oleh PT Ramjaya Copier sudah menunjukan hasil yang baik dengan rata-rata tingkat kepuasan mencapai $75 \%$

\section{METODE PENELITIAN Desain/Jenis Penelitian}

Penelitian ini merupakan penelitian deskriptif, yakni penelitian yang dilakukan untuk mengetahui nilai variabel mandiri baik satu variabel atau lebih variabel tanpa membuat perbandingan atau menghubungkan anara variabel satu dengan variabel lain dan dinyatakan dalam bentuk angka - angka.

\section{Objek dan Ruang Lingkup Penelitian}

Objek dalam penelitian ini adalah seluruh pelanggan PT Ramajaya Copier. Ruang lingkup penelitian ini adalah kualitas pelayanan yang diberikan PT Ramajaya Copier kepada pelanggan.

\section{Operasionalisasi Variabel}

Definisi operasionalisasi variabel berisi indikator-indikator suatu variabel, yang memungkinkan peneliti mengumpul data yang relevan untuk variabel tersebut. Definisi operasional masing-masing variabel dan indikatornya sebagai berikut:
1. Bukti Fisik X1 Meliputi fasilitas fisik, perlengkapan pegawai dan sarana komunikasi

2. Kehandalan X2 Kemampuan memberikan pelayanan yang dijanjikan dengan segera, akurat dan memuaskan

3. Daya tanggap X3 Dimensi ini menekankan pada perhatian penuh dan kecepatan dalam melakukan hubungan dengan para pelang gan baik permintaan pertanyaan keluhan dan masalahmasalah

4. Jaminan X2 Mencakup pengetahuan, kemampuan, kesopanan dan sifat dapat dipercaya yang dimiliki para staf, bebas dari bahaya, resiko atau keragu-raguan

5. Empati X3 Meliputi kemudahan dalam melakukan hubungan komunikasi yang baik, perhatian pribadi dan memahami kebutuhan para pelanggan

6. Kepuasan pelayanan Y Kepuasan pelanggan

\section{Populasi}

Populasi adalah wilayah generalisasi yang terdiri atas objek/subjek yang mempunyai kualitas dan karakteristik tertentu. Oleh karena itu, populasi dalam penelitian ini adalah seluruh pelanggan/pelanggan PT Ramajaya Copier di Batam berjumlah 93 pelanggan.

\section{Sampel}

Sampel adalah sebagian dari jumlah dan karakteristik yang dimiliki oleh populasi tersebut Sugiyono, (2016). Oleh karena jumlah pelanggan PT Ramajaya Copier Batam berjumlah 93 responden, maka yang menjadi sampel dalam penelitian ini dengan menggunakan metode simple random sampling adalah keseluruhan dari populasi yakni 93 responden.

\section{Jenis dan Sumber Data}

Jenis data yang digunakan dalam penelitian analisis kepuasan pelanggan terhadap kualitas pelayanan di PT Ramajaya Copier adalah:

1. Data primer, merupakan data yang langsung diberikan kepada pengumpul data Sugiyono, (2010). Dalam penelitian 
ini data primer berupa data olahan yang berasal dari kuesioner penelitian.

2. Data sekunder, merupakan data yang tidak langsung memberikan data kepada kepada pengumpul data, dapat diperoleh dari cerita, literatur, buku dsb, Sugiyono, (2010). Dalam penelitian ini data sekunder yang digunakan berupa dokumen perusahaan yang dapat mendukung penelitian ini.

\section{Teknik Pengumpulan Data}

Adapun teknik pengumpulan data yang dilakukan dalam penelitian

analisis kepuasan pelanggan terhadap kualitas pelayanan di PT Ramajaya Copier adalah:

1. Kuesioner, merupakan teknik pengumpulan data yang dilakukan dengan memberi seperangkat pertanyaan atau pernyataan tertulis kepada responden untuk dijawabnya Sugiyono (2016).

2. Dokumentasi, merupakan catatan peristiwa yang sudah berlalu (Sugiyono, 2016).

3. Observasi, merupakan proses penelitian dengan mengamati objek yang digunakan sebagai sumber data penelitian (Sugiyono, 2016).

\section{Validitas dan Reliabilitas}

\section{Uji Validitas}

Uji Validitas merupakan derajad ketepatan antara data yang terjadi pada objek penelitian dengan data yang dilaporkan Sugiyono, (2014). Untuk menguji validitas konstruk dilakukan dengan mengkorelasikan antara skor butir pertanyaan dengan skor totalnya. Masing-masing item (skor butir) dilihat harga korelasinya. Bila harga korelasi positif dan $r>0,3$ maka butir instrumen tersebut dinyatakan valid. Data yang terkumpul diuji keabsahannya dengan uji validitas menggunakan korelasi product moment dengan rumus:

$$
r_{x y}=\frac{N \sum X Y-\left(\sum X\right)\left(\sum Y\right)}{\sqrt{\left(N \sum X^{2}-\left(\sum X\right)^{2}-N \sum Y^{2}-\left(\sum Y\right)^{2}\right)}}
$$

Dimana:

$\begin{array}{lll}\mathrm{N} & : & \text { Jumlah responden } \\ & : & \text { Koefisien korelasi antara } \mathrm{X} \text { dan } \\ \mathrm{r}_{\mathrm{xy}} & & \mathrm{Y} \\ \Sigma \mathrm{XY} & : & \text { Jumlah Perkalian antara variabel } \\ \mathrm{X} \text { dan } \mathrm{Y} \\ \sum \mathrm{X}^{2} & : & \text { Jumlah dari kuadrat nilai } \mathrm{X} \\ \sum \mathrm{Y}^{2} & : & \text { Jumlah dari kuadrat nilai } \mathrm{Y} \\ \left(\sum \mathrm{X}\right)^{2} & : & \text { Jumlah Nilai } \mathrm{X} \text { kemudian } \\ & & \text { dikuadratkan } \\ \left(\sum \mathrm{Y}\right)^{2} & : & \text { Jumlah Nilai } \mathrm{Y} \text { kemudian } \\ \mathrm{X} & : & \text { dikuadratkan } \\ \mathrm{Y} & : & \text { Skor variabel independen } \mathrm{X} \\ & & \text { Skor variabel independen } \mathrm{Y}\end{array}$

Hasil pengujian validitas semua item pada setiap instrumen penelitian dangan taraf signifikasi $\alpha=5 \%$, jumlah responden sebanyak 93 responden, dan $r$ tabel $=0,205$ adalah sebagai berikut:

Tabel 3.3 Rekapitulasi hasil uji validitas instrumen penelitian Harapan dan Kinerja

\begin{tabular}{|c|c|c|c|c|c|c|c|}
\hline \multirow[b]{2}{*}{$\begin{array}{l}\text { Vari } \\
\text { abel }\end{array}$} & & \multirow[b]{2}{*}{ Item } & \multicolumn{5}{|c|}{ Validitas } \\
\hline & & & $\begin{array}{l}\text { Nila } \\
\text { i } \\
\text { Kor } \\
\text { elasi }\end{array}$ & $\begin{array}{l}\text { Har } \\
\text { apan }\end{array}$ & $\begin{array}{l}\text { Kin } \\
\text { erja }\end{array}$ & $\begin{array}{c}\text { Taraf } \\
\text { Signif } \\
\text { ikan }\end{array}$ & $\begin{array}{l}\mathrm{K} \\
\mathrm{e} \\
\mathrm{t}\end{array}$ \\
\hline \multirow{6}{*}{$\begin{array}{c}\text { Bukt } \\
\text { i } \\
\text { Fisi } \\
\text { k }\end{array}$} & $\begin{array}{l}\mathrm{P} \\
1\end{array}$ & $\begin{array}{l}\text { Perusahaa } \\
\mathrm{n} \text { memiliki } \\
\text { fasilitas } \\
\text { kantor dan } \\
\text { permesina } \\
\mathrm{n} \\
\text { penunjang } \\
\text { pelayanan } \\
\text { yang } \\
\text { memadai }\end{array}$ & $\begin{array}{c}0,20 \\
5\end{array}$ & $\begin{array}{c}0,66 \\
4\end{array}$ & $\begin{array}{l}0,8 \\
94\end{array}$ & $\begin{array}{l}0 \\
5 \\
\%\end{array}$ & $\begin{array}{l}\mathrm{V} \\
\mathrm{a} \\
\mathrm{l} \\
\mathrm{i} \\
\mathrm{d}\end{array}$ \\
\hline & $\begin{array}{l}\mathrm{P} \\
2\end{array}$ & $\begin{array}{l}\text { Karyawan } \\
\text { perusahan } \\
\text { berpakaian } \\
\text { rapi dan } \\
\text { menarik } \\
\text { saat } \\
\text { memberik } \\
\text { an } \\
\text { pelayanan }\end{array}$ & $\begin{array}{c}0,20 \\
5\end{array}$ & $\begin{array}{c}0,76 \\
9\end{array}$ & $\begin{array}{l}0,3 \\
94\end{array}$ & $0.5 \%$ & $\begin{array}{l}\mathrm{V} \\
\mathrm{a} \\
1 \\
\mathrm{i} \\
\mathrm{d}\end{array}$ \\
\hline & $\begin{array}{l}\mathrm{P} \\
3\end{array}$ & $\begin{array}{l}\text { Kebersiha } \\
\mathrm{n} \\
\text { perusahaa } \\
\mathrm{n} \text { terjaga }\end{array}$ & $\begin{array}{c}0,20 \\
5\end{array}$ & $\begin{array}{c}0,72 \\
4\end{array}$ & $\begin{array}{c}0,8 \\
30\end{array}$ & $0.5 \%$ & $\begin{array}{l}\mathrm{V} \\
\mathrm{a} \\
1 \\
\mathrm{i} \\
\mathrm{d}\end{array}$ \\
\hline & $\begin{array}{l}\mathrm{P} \\
4\end{array}$ & $\begin{array}{l}\text { Perusahaa } \\
\text { n memiliki } \\
\text { lokasi } \\
\text { usaha } \\
\text { yang } \\
\text { strategis } \\
\text { dan mudah } \\
\text { dijangkau }\end{array}$ & $\begin{array}{c}0,20 \\
5\end{array}$ & $\begin{array}{c}0,74 \\
3\end{array}$ & $\begin{array}{l}0,7 \\
34\end{array}$ & $0.5 \%$ & $\begin{array}{l}\mathrm{V} \\
\mathrm{a} \\
1 \\
\mathrm{i} \\
\mathrm{d}\end{array}$ \\
\hline & $\begin{array}{l}P \\
5\end{array}$ & $\begin{array}{l}\text { Perusahaa } \\
\mathrm{n} \text { memiliki } \\
\text { contact } \\
\text { person } \\
\text { yang jelas }\end{array}$ & $\begin{array}{c}0,20 \\
5\end{array}$ & $\begin{array}{c}0,62 \\
2\end{array}$ & $\begin{array}{l}0,7 \\
59\end{array}$ & $0.5 \%$ & $\begin{array}{l}\mathrm{V} \\
\mathrm{a} \\
1 \\
\mathrm{i} \\
\mathrm{d}\end{array}$ \\
\hline & $\begin{array}{l}P \\
6\end{array}$ & $\begin{array}{l}\text { Tersedia } \\
\text { layananan }\end{array}$ & $\begin{array}{c}0,20 \\
5\end{array}$ & $\begin{array}{c}0,77 \\
0\end{array}$ & $\begin{array}{l}0,8 \\
84\end{array}$ & $0.5 \%$ & $\begin{array}{l}\mathrm{V} \\
\mathrm{a}\end{array}$ \\
\hline
\end{tabular}


Journal of Applied Business Administration Vol 3, No 1, Maret 2019, hlm. 119-131.

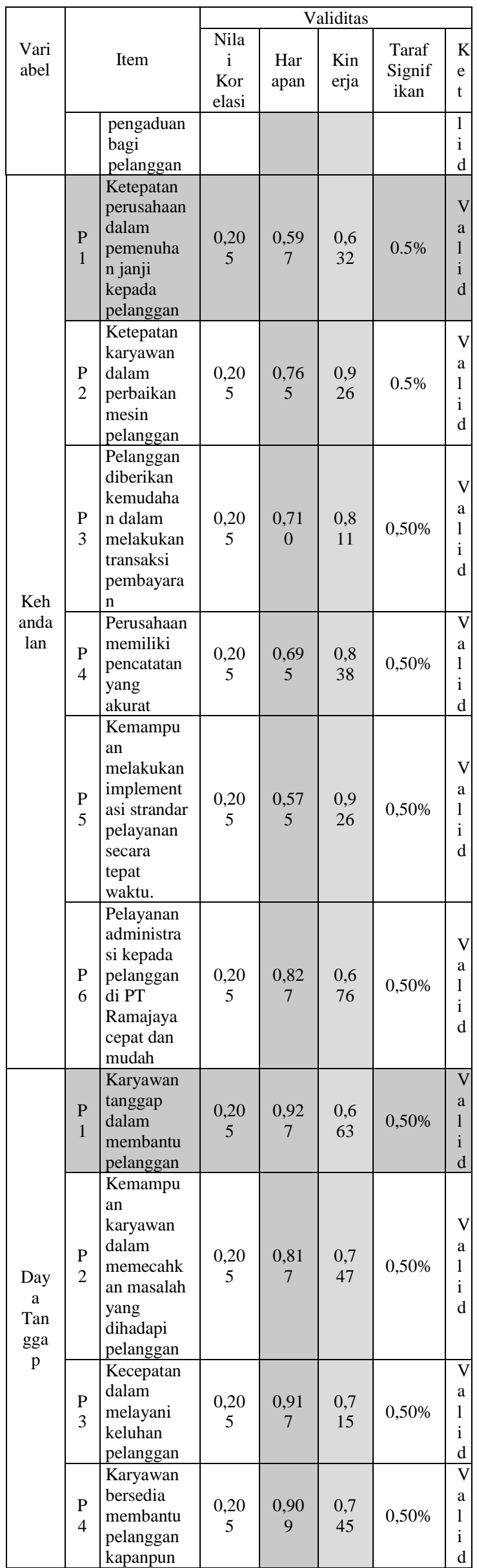

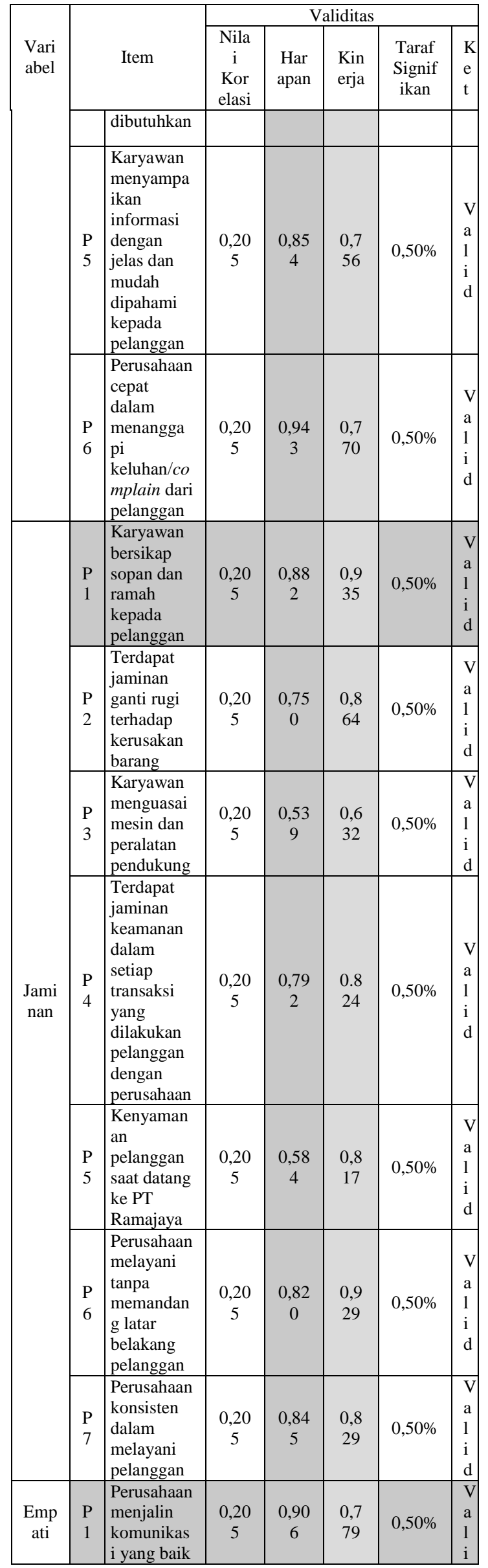




\begin{tabular}{|c|c|c|c|c|c|c|c|}
\hline \multirow[b]{2}{*}{$\begin{array}{l}\text { Vari } \\
\text { abel }\end{array}$} & & \multirow[b]{2}{*}{ Item } & \multicolumn{5}{|c|}{ Validitas } \\
\hline & & & $\begin{array}{c}\text { Nila } \\
\text { i } \\
\text { Kor } \\
\text { elasi }\end{array}$ & $\begin{array}{c}\text { Har } \\
\text { apan }\end{array}$ & $\begin{array}{l}\text { Kin } \\
\text { erja }\end{array}$ & $\begin{array}{c}\text { Taraf } \\
\text { Signif } \\
\text { ikan }\end{array}$ & \\
\hline & & $\begin{array}{l}\text { kepada } \\
\text { pelanggan }\end{array}$ & & & & & $\mathrm{d}$ \\
\hline & $\begin{array}{l}P \\
2\end{array}$ & $\begin{array}{l}\text { Perusahaan } \\
\text { memberika } \\
\mathrm{n} \text { toleransi } \\
\text { terhadap } \\
\text { keterlamba } \\
\text { tan } \\
\text { pembayara } \\
\text { n kepada } \\
\text { pelanggan }\end{array}$ & $\begin{array}{c}0,20 \\
5\end{array}$ & $\begin{array}{c}0,50 \\
4\end{array}$ & $\begin{array}{c}0,8 \\
15\end{array}$ & $0,50 \%$ & $\begin{array}{l}\mathrm{V} \\
\mathrm{a} \\
\mathrm{l} \\
\mathrm{i} \\
\mathrm{d}\end{array}$ \\
\hline & $\begin{array}{l}\mathrm{P} \\
3\end{array}$ & $\begin{array}{l}\text { Karyawan } \\
\text { paham } \\
\text { terhadap } \\
\text { keluhan } \\
\text { dan } \\
\text { keinginan } \\
\text { pelanggan }\end{array}$ & $\begin{array}{c}0,20 \\
5\end{array}$ & $\begin{array}{c}0,90 \\
6\end{array}$ & $\begin{array}{l}0,5 \\
81\end{array}$ & $0,50 \%$ & $\begin{array}{l}\mathrm{V} \\
\mathrm{a} \\
\mathrm{l} \\
\mathrm{i} \\
\mathrm{d}\end{array}$ \\
\hline & $\begin{array}{l}\mathrm{P} \\
4\end{array}$ & $\begin{array}{l}\text { Penggunaa } \\
\text { n seragam } \\
\text { pada } \\
\text { karyawan }\end{array}$ & $\begin{array}{c}0,20 \\
5\end{array}$ & $\begin{array}{c}0,89 \\
9\end{array}$ & $\begin{array}{l}0,4 \\
79\end{array}$ & $0,50 \%$ & $\begin{array}{l}\mathrm{V} \\
\mathrm{a} \\
1 \\
\mathrm{i} \\
\mathrm{d}\end{array}$ \\
\hline & $\begin{array}{l}\mathrm{P} \\
5\end{array}$ & $\begin{array}{l}\text { Karyawan } \\
\text { mengguna } \\
\text { kan tanda } \\
\text { pengenal }\end{array}$ & $\begin{array}{c}0,20 \\
5\end{array}$ & $\begin{array}{c}0,94 \\
1\end{array}$ & $\begin{array}{l}0,3 \\
88\end{array}$ & $0,50 \%$ & $\begin{array}{l}\mathrm{V} \\
\mathrm{a} \\
1 \\
\mathrm{i} \\
\mathrm{d}\end{array}$ \\
\hline & $\begin{array}{l}P \\
6\end{array}$ & $\begin{array}{l}\text { Karyawan } \\
\text { menjawab } \\
\text { pertanyaan } \\
\text { dari } \\
\text { pelanggan } \\
\text { dengan } \\
\text { baik } \\
\end{array}$ & $\begin{array}{c}0,20 \\
5\end{array}$ & 0,80 & $\begin{array}{l}0,7 \\
79\end{array}$ & $0,50 \%$ & $\begin{array}{l}\mathrm{V} \\
\mathrm{a} \\
\mathrm{l} \\
\mathrm{i} \\
\mathrm{d}\end{array}$ \\
\hline \multirow{5}{*}{$\begin{array}{c}\text { Kep } \\
\text { uasa } \\
n \\
\text { Pela } \\
\text { yana } \\
\text { n }\end{array}$} & $\begin{array}{l}P \\
1\end{array}$ & $\begin{array}{l}\text { Pelanggan } \\
\text { senang } \\
\text { dengan } \\
\text { pelayanan } \\
\text { yang } \\
\text { diberikan } \\
\text { perusahaan }\end{array}$ & $\begin{array}{c}0,20 \\
5\end{array}$ & $\begin{array}{c}0,84 \\
2\end{array}$ & $\begin{array}{l}0,7 \\
65\end{array}$ & $0,50 \%$ & $\begin{array}{l}\mathrm{V} \\
\mathrm{a} \\
\mathrm{l} \\
\mathrm{i} \\
\mathrm{d}\end{array}$ \\
\hline & $\begin{array}{l}P \\
2\end{array}$ & $\begin{array}{l}\text { Pelanggan } \\
\text { bersedia } \\
\text { merekome } \\
\text { ndasikan } \\
\text { perusahaan }\end{array}$ & $\begin{array}{c}0,20 \\
5\end{array}$ & $\begin{array}{c}0,78 \\
4\end{array}$ & $\begin{array}{l}0,7 \\
69\end{array}$ & $0,50 \%$ & $\begin{array}{l}\mathrm{V} \\
\mathrm{a} \\
\mathrm{l} \\
\mathrm{i} \\
\mathrm{d}\end{array}$ \\
\hline & $\begin{array}{l}\mathrm{P} \\
3\end{array}$ & $\begin{array}{l}\text { Pelayanan } \\
\text { yang } \\
\text { diberikan } \\
\text { PT } \\
\text { Ramajaya } \\
\text { Copier } \\
\text { sesuai } \\
\text { dengan } \\
\text { harapan } \\
\end{array}$ & $\begin{array}{c}0,20 \\
5\end{array}$ & $\begin{array}{c}0,88 \\
4\end{array}$ & $\begin{array}{c}0,4 \\
30\end{array}$ & $0,50 \%$ & $\begin{array}{l}\mathrm{V} \\
\mathrm{a} \\
\mathrm{l} \\
\mathrm{i} \\
\mathrm{d}\end{array}$ \\
\hline & $\begin{array}{l}\mathrm{P} \\
4\end{array}$ & $\begin{array}{l}\text { Pelanggan } \\
\text { tidak } \\
\text { berniat } \\
\text { mengguna } \\
\text { kan jasa } \\
\text { perusahaan } \\
\text { lain } \\
\end{array}$ & $\begin{array}{c}0,20 \\
5\end{array}$ & $\begin{array}{c}0,83 \\
0\end{array}$ & $\begin{array}{l}0,7 \\
69\end{array}$ & $0,50 \%$ & $\begin{array}{l}\mathrm{V} \\
\mathrm{a} \\
\mathrm{l} \\
\mathrm{i} \\
\mathrm{d}\end{array}$ \\
\hline & $\begin{array}{l}P \\
5\end{array}$ & $\begin{array}{l}\text { Pelanggan } \\
\text { berkeiningi } \\
\text { nan } \\
\text { memberika } \\
\text { n masukan } \\
\text { kepada } \\
\text { perusahaan }\end{array}$ & $\begin{array}{c}0,20 \\
5\end{array}$ & $\begin{array}{c}0,86 \\
8\end{array}$ & $\begin{array}{l}0,7 \\
63\end{array}$ & $0,50 \%$ & $\begin{array}{l}\mathrm{V} \\
\mathrm{a} \\
\mathrm{l} \\
\mathrm{i} \\
\mathrm{d}\end{array}$ \\
\hline
\end{tabular}

Sumber: Data Olahan Peneliti, (2018)

Berdasarkan data hasil pengujian validitas pada Tabel 3.3 instrumen Harapan dan Kinerja hasil pengujian menunjukan bahwa signifikasi koefisien korelasi seluruh item lebih besar yaitu $r>0,205$. Sehingga dapat disimpulkan bahwa seluruh item yang diuji dalam penelitian adalah valid.

\section{Uji Reliabilitas}

Suatu kuesioner dikatakan reliabel atau dapat dipercaya jika jawaban seseorang terhadap suatu pertanyaan adalah konsisten atau stabil dari waktu ke waktu Sugiyono (2016). Pengujian reliabilitas instrumen menggunakan teknik alpha cronbach. Reliabilitas instrumen dianggap dapat dipercaya jika memiliki koefisien reliabilitas alpha > 0,60 Sugiyono (2016). Teknik ini cocok untuk menguji skala instrumen yang masing-masing butirnya mempunyai lebih dari satu alternatif jawaban. Suatu instrumen yang reliabel jika memiliki koefisien Cronbach Alpha diatas 0,60. Untuk menghitung reabilitas menggunakan rumus alpha, sebagai berikut: $r_{11}=\frac{k}{k-1} \times\left\{1-\frac{\sum s_{i}}{s_{t}}\right\}$

Dimana:

$\mathrm{r}_{11} \quad=$ Nilai reliabilitas

$\sum \mathrm{S}_{\mathrm{i}} \quad=$ Jumlah varians tiap item

$\mathrm{S}_{\mathrm{t}} \quad=$ Varians total

$\mathrm{k}=$ Jumlah item

Berdasarkan koefisien reliabilitas yang dipilih adalah $\alpha \geq 0,6$ karena memiliki kriteria yang dianggap cukup. Sehingga keputusan uji tes ini adalah sebagai berikut:

a. Bila nilai Alpha Cronbach $\geq$ konsta 0,6, maka pernyataan reliabel

b. Bila nilai Alpha Cronbach < konsta 0,6, maka pernyataan tidak reliabel

Hasil pengujian reliabilitas instrument penelitian yang berjumlah 5 (Lima) instrumen variable pelayanan dan 1 (Satu) variabel kepuasan pelanggan dengan rentang interprestasi cukup 0,7>a>0,6 adalah sebagai berikut: 
Journal of Applied Business Administration Vol 3, No 1, Maret 2019, hlm. 119-131.

Tabel 3.5 Rekapitulasi Hasil Uji Reliabilitas Harapan dan Kinerja

\begin{tabular}{|c|c|c|c|}
\hline Variabel & $\begin{array}{c}\text { Alpha } \\
\text { Cronba } \\
\text { ch } \\
\text { Harapa } \\
\text { n }\end{array}$ & $\begin{array}{c}\text { Alpha } \\
\text { Cronba } \\
\text { ch } \\
\text { Kinerja }\end{array}$ & $\begin{array}{c}\text { Keteran } \\
\text { gan }\end{array}$ \\
\hline Bukti Fisik & 0,819 & 0,845 & Reliabel \\
\hline Kehandalan & 0,795 & 0,891 & Reliabel \\
\hline Daya Tanggap & 0,950 & 0,828 & Reliabel \\
\hline Jaminan & 0,867 & 0,936 & Reliabel \\
\hline Empati & 0,916 & 0,707 & Reliabel \\
\hline $\begin{array}{c}\text { Kepuasan } \\
\text { Pelayanan }\end{array}$ & 0,897 & 0,740 & Reliabel \\
\hline
\end{tabular}

Sumber: Data Olahan Peneliti, (2018)

Berdasarkan data hasil pengujian reliabilitas pada Tabel 3.5 diatas, instrumen Harapan dan Kinerja hasil pengujian menunjukan bahwa nilai Alpha Cronbach yang dihasilkan oleh setiap item pernyataan menunjukan angka $>0,6$. Sehingga dapat disimpulkan bahwa ke- 6 (Enam) variabel penelitian tersebut dapat dinyatakan reliabel.

\section{Metode Analisis Data}

\section{Analisis Statistik Deskriptif}

Analisis statistik deskriptif adalah statistik yang digunakan untuk menganalisis data dengan mendeskripsikan atau menggambarkan data yang telah terkumpul sebagaimana adanya tanpa bermaksud membuat kesimpulan yang berlaku untuk umum atau generalisasi Sugiyono, (2014). Mendeskripsikan atau menggambarkan data yang telah terkumpul dapat dilihat dari nilai maksimum, minimum, rata-rata (mean) dan standart deviasi.

\section{Importance Performance Analysis (IPA)}

Sebelum memetakan kedalam kuadran terlebih dahulu menghitung tingkat kesesuaian rata-rata antara harapan dan kinerja. Tingkat kesesuaian merupakan hasil perbandingan skor kinerja/pelaksanaan dengan sekor harapan. Tingkat kesesuaian responden diukur berdasarkan tingkat persentase sebagai berikut:

Tabel 4.13 Tingkat Kesesuaian Rata-Rata antara Harapan dan Kinerja

\begin{tabular}{|c|c|c|c|c|}
\hline Rata-Rata & $\begin{array}{c}\text { Hara } \\
\text { pan }\end{array}$ & $\underset{\text { ja }}{\text { Kiner }}$ & $\begin{array}{c}\text { Tingkat } \\
\text { Kesesuai } \\
\text { an }\end{array}$ & Kategori \\
\hline $\begin{array}{l}\text { Perusahaan } \\
\text { memiliki } \\
\text { fasilitas kantor } \\
\text { dan permesinan } \\
\text { penunjang } \\
\text { pelayanan yang } \\
\text { memadai }\end{array}$ & 3,12 & 2,87 & 91,99 & $\begin{array}{l}\text { Sangat } \\
\text { Memuask } \\
\text { an/Baik }\end{array}$ \\
\hline $\begin{array}{l}\text { Karyawan } \\
\text { perusahan } \\
\text { berpakaian rapi } \\
\text { dan menarik } \\
\text { saat } \\
\text { memberikan } \\
\text { pelayanan }\end{array}$ & 3,03 & 3,29 & 108,58 & $\begin{array}{l}\text { Melebihi } \\
\text { Harapan } \\
\text { Konsume } \\
\mathrm{n}\end{array}$ \\
\hline $\begin{array}{l}\text { Kebersihan } \\
\text { perusahaan } \\
\text { terjaga }\end{array}$ & 3,31 & 2,49 & 75,23 & $\begin{array}{l}\text { Cukup } \\
\text { Memuask } \\
\text { an/Cukup } \\
\text { Baik }\end{array}$ \\
\hline $\begin{array}{l}\text { Perusahaan } \\
\text { memiliki lokasi } \\
\text { usaha yang } \\
\text { strategis dan } \\
\text { mudah } \\
\text { dijangkau }\end{array}$ & 3,01 & 2,08 & 69,10 & $\begin{array}{l}\text { Cukup } \\
\text { Memuask } \\
\text { an/Cukup } \\
\text { Baik }\end{array}$ \\
\hline $\begin{array}{l}\text { Perusahaan } \\
\text { memiliki } \\
\text { contact person } \\
\text { yang jelas }\end{array}$ & 3,14 & 2,54 & 80,89 & $\begin{array}{l}\text { Memuask } \\
\text { an/Baik }\end{array}$ \\
\hline $\begin{array}{l}\text { Tersedia } \\
\text { layananan } \\
\text { pengaduan bagi } \\
\text { pelanggan }\end{array}$ & 3,33 & 2,89 & 86,79 & $\begin{array}{l}\text { Sangat } \\
\text { Memuask } \\
\text { an/Baik }\end{array}$ \\
\hline $\begin{array}{l}\text { Ketepatan } \\
\text { perusahaan } \\
\text { dalam } \\
\text { pemenuhan } \\
\text { janji kepada } \\
\text { pelanggan }\end{array}$ & 3,16 & 2,99 & 94,62 & $\begin{array}{l}\text { Sangat } \\
\text { Memuask } \\
\text { an/Baik }\end{array}$ \\
\hline $\begin{array}{l}\text { Ketepatan } \\
\text { karyawan } \\
\text { dalam } \\
\text { perbaikan } \\
\text { mesin } \\
\text { pelanggan } \\
\end{array}$ & 3,39 & 3,04 & 89,68 & $\begin{array}{l}\text { Sangat } \\
\text { Memuask } \\
\text { an/Baik }\end{array}$ \\
\hline $\begin{array}{l}\text { Pelanggan } \\
\text { diberikan } \\
\text { kemudahan } \\
\text { dalam } \\
\text { melakukan } \\
\text { transaksi } \\
\text { pembayaran }\end{array}$ & 3,46 & 2,87 & 82,95 & $\begin{array}{l}\text { Memuask } \\
\text { an/Baik }\end{array}$ \\
\hline $\begin{array}{l}\text { Perusahaan } \\
\text { memiliki } \\
\text { pencatatan yang } \\
\text { akurat }\end{array}$ & 3,33 & 2,61 & 78,38 & $\begin{array}{l}\text { Memuask } \\
\text { an/Baik }\end{array}$ \\
\hline $\begin{array}{l}\text { Kemampuan } \\
\text { melakukan } \\
\text { implementasi } \\
\text { strandar } \\
\text { pelayanan } \\
\text { secara tepat } \\
\text { waktu }\end{array}$ & 3,14 & 3,04 & 96,82 & $\begin{array}{l}\text { Sangat } \\
\text { Memuask } \\
\text { an/Baik }\end{array}$ \\
\hline $\begin{array}{l}\text { Pelayanan } \\
\text { administrasi } \\
\text { kepada } \\
\text { pelanggan di } \\
\text { PT Ramajaya } \\
\text { cepat dan } \\
\text { mudah } \\
\end{array}$ & 3,52 & 3,09 & 87,78 & $\begin{array}{l}\text { Sangat } \\
\text { Memuask } \\
\text { an/Baik }\end{array}$ \\
\hline
\end{tabular}




\begin{tabular}{|c|c|c|c|c|}
\hline Rata-Rata & $\begin{array}{c}\text { Hara } \\
\text { pan }\end{array}$ & $\begin{array}{c}\text { Kiner } \\
\text { ja }\end{array}$ & $\begin{array}{l}\text { Tingkat } \\
\text { Kesesuai } \\
\text { an }\end{array}$ & Kategori \\
\hline $\begin{array}{l}\text { Karyawan } \\
\text { tanggap dalam } \\
\text { membantu } \\
\text { pelanggan }\end{array}$ & 3,29 & 2,61 & 79,33 & $\begin{array}{l}\text { Memuask } \\
\text { an/Baik }\end{array}$ \\
\hline $\begin{array}{l}\text { Kemampuan } \\
\text { karyawan } \\
\text { dalam } \\
\text { memecahkan } \\
\text { masalah yang } \\
\text { dihadapi } \\
\text { pelanggan }\end{array}$ & 3,31 & 3,09 & 93,35 & $\begin{array}{l}\text { Sangat } \\
\text { Memuask } \\
\text { an/Baik }\end{array}$ \\
\hline $\begin{array}{l}\text { Kecepatan } \\
\text { dalam melayani } \\
\text { keluhan } \\
\text { pelanggan }\end{array}$ & 3,28 & 2,88 & 87,80 & $\begin{array}{l}\text { Sangat } \\
\text { Memuask } \\
\text { an/Baik }\end{array}$ \\
\hline $\begin{array}{l}\text { Karyawan } \\
\text { bersedia } \\
\text { membantu } \\
\text { pelanggan } \\
\text { kapanpun } \\
\text { dibutuhkan } \\
\end{array}$ & 3,29 & 2,41 & 73,25 & $\begin{array}{l}\text { Cukup } \\
\text { Memuask } \\
\text { an }\end{array}$ \\
\hline $\begin{array}{l}\text { Karyawan } \\
\text { penyampaikan } \\
\text { informasi } \\
\text { dengan jelas } \\
\text { dan mudah } \\
\text { dipahami } \\
\text { kepada } \\
\text { pelanggan } \\
\end{array}$ & 3,30 & 2,78 & 84,24 & $\begin{array}{l}\text { Memuask } \\
\text { an/Baik }\end{array}$ \\
\hline $\begin{array}{l}\text { Perusahaan } \\
\text { cepat dalam } \\
\text { menanggapi } \\
\text { keluhan/compla } \\
\text { in dari } \\
\text { pelanggan }\end{array}$ & 3,32 & 2,82 & 84,94 & $\begin{array}{l}\text { Memuask } \\
\text { an/Baik }\end{array}$ \\
\hline $\begin{array}{l}\text { Karyawan } \\
\text { bersikap sopan } \\
\text { dan ramah } \\
\text { kepada } \\
\text { pelanggan }\end{array}$ & 3,47 & 2,61 & 75,22 & $\begin{array}{l}\text { Cukup } \\
\text { Memuask } \\
\text { an }\end{array}$ \\
\hline $\begin{array}{l}\text { Terdapat } \\
\text { jaminan ganti } \\
\text { rugi terhadap } \\
\text { kerusakan } \\
\text { barang }\end{array}$ & 3,41 & 3,04 & 89,15 & $\begin{array}{l}\text { Sangat } \\
\text { Memuask } \\
\text { an/Baik }\end{array}$ \\
\hline $\begin{array}{l}\text { Karyawan } \\
\text { menguasai } \\
\text { mesin dan } \\
\text { peralatan } \\
\text { pendukung }\end{array}$ & 3,47 & 3,09 & 89,05 & $\begin{array}{l}\text { Sangat } \\
\text { Memuask } \\
\text { an/Baik }\end{array}$ \\
\hline $\begin{array}{l}\text { Terdapat } \\
\text { jaminan } \\
\text { keamanan } \\
\text { dalam setiap } \\
\text { transaksi yang } \\
\text { dilakukan } \\
\text { pelanggan } \\
\text { dengan } \\
\text { perusahaan } \\
\end{array}$ & 3,42 & 2,87 & 83,92 & $\begin{array}{l}\text { Memuask } \\
\text { an/Baik }\end{array}$ \\
\hline $\begin{array}{l}\text { Kenyamanan } \\
\text { pelanggan saat } \\
\text { datang ke PT } \\
\text { Ramajaya }\end{array}$ & 3,48 & 2,59 & 74,43 & $\begin{array}{l}\text { Cukup } \\
\text { Memuask } \\
\text { an }\end{array}$ \\
\hline $\begin{array}{l}\text { Perusahaan } \\
\text { melayani tanpa } \\
\text { memandang } \\
\text { latar belakang } \\
\text { pelanggan }\end{array}$ & 3,44 & 2,61 & 75,87 & $\begin{array}{l}\text { Cukup } \\
\text { Memuask } \\
\text { an }\end{array}$ \\
\hline
\end{tabular}

\begin{tabular}{|l|c|c|c|l|}
\hline \multicolumn{1}{|c|}{ Rata-Rata } & $\begin{array}{c}\text { Hara } \\
\text { pan }\end{array}$ & $\begin{array}{c}\text { Kiner } \\
\text { ja }\end{array}$ & $\begin{array}{c}\text { Tingkat } \\
\text { Kesesuai } \\
\text { an }\end{array}$ & Kategori \\
\hline $\begin{array}{l}\text { Perusahaan } \\
\text { konsisten dalam } \\
\text { melayani } \\
\text { pelanggan }\end{array}$ & 3,47 & 2,87 & 82,71 & $\begin{array}{l}\text { Memuask } \\
\text { an/Baik }\end{array}$ \\
\hline $\begin{array}{l}\text { Perusahaan } \\
\text { menjalin } \\
\text { komunikasi } \\
\text { yang baik } \\
\text { kepada } \\
\text { pelanggan }\end{array}$ & 3,41 & 3,04 & 89,15 & $\begin{array}{l}\text { Memuask } \\
\text { an/Baik }\end{array}$ \\
\hline $\begin{array}{l}\text { Perusahaan } \\
\text { memberikan } \\
\text { toleransi } \\
\text { terhadap } \\
\text { keterlambatan } \\
\text { pembayaran } \\
\text { kepada } \\
\text { pelanggan }\end{array}$ & 3,49 & 2,61 & 74,79 & $\begin{array}{l}\text { Memuask } \\
\text { an }\end{array}$ \\
\hline $\begin{array}{l}\text { Karyawan } \\
\text { paham terhadap } \\
\text { keluhan dan } \\
\text { keinginan } \\
\text { pelanggan }\end{array}$ & 3,42 & 3,09 & 90,35 & $\begin{array}{l}\text { Memuask } \\
\text { an/Baik }\end{array}$ \\
\hline $\begin{array}{l}\text { Penggunaan } \\
\text { seragam pada } \\
\text { karyawan }\end{array}$ & 3,43 & 2,88 & 83,97 & $\begin{array}{l}\text { Memuask } \\
\text { an/Baik }\end{array}$ \\
\hline $\begin{array}{l}\text { Karyawan } \\
\text { menggunakan } \\
\text { tanda pengenal }\end{array}$ & 3,45 & 3,29 & 95,36 & $\begin{array}{l}\text { Sangat } \\
\text { Memuask } \\
\text { an/Baik }\end{array}$ \\
\hline $\begin{array}{l}\text { Karyawan } \\
\text { menjawab } \\
\text { pertanyaan dari } \\
\text { pelanggan } \\
\text { dengan baik }\end{array}$ & 3,49 & 3,04 & 87,11 & $\begin{array}{l}\text { Memuask } \\
\text { an/Baik }\end{array}$ \\
\hline Rata-Rata & 3,34 & 2,84 & $\begin{array}{l}\text { Memuask } \\
\text { an/Baik }\end{array}$ \\
\hline Sumber: Data Olangat \\
\hline
\end{tabular}

Sumber: Data Olahan Peneliti (2018)

Pada Tabel 4.12 menunjukan rata rata tingkat kesesuaian secara keseluruhan sebesar $85,6 \%$ dengan rentang tingkat kesesuaian 69,0\% - 108,58. Maka dapat dikatakan bahwa kinerja secara keseluruhan indikator pernyataan telah dapat memuaskan/baik namun belum melebihi harapan konsumen sehingga masih perlu di perbaiki lagi. Indikator pernyataan yang memiliki nilai $69,0 \%$ merupakan indikator pernyataan perusahaan memiliki lokasi usaha yang strategis dan mudah dijangkau yang dirasa konsumen jauh dari harapan. Indikator pernyataan yang memiliki nilai 108,58 merupakan indikator pernyataan karyawan perusahan berpakaian rapi dan menarik saat memberikan pelayanan telah melebihi harapan konsumen sehingga PT Ramajaya perlu mempertahankan kualitasnya.

Nilai rata - rata harapan sebesar 3,34 dan nilai rata - rata kinerja sebesar 2,84. Nilai rata - rata tersebut akan digunakan 
untuk menentukan diagram kartesius. Berikut penjabaran kuadran importance performance analysis (Diagram Kartesius):

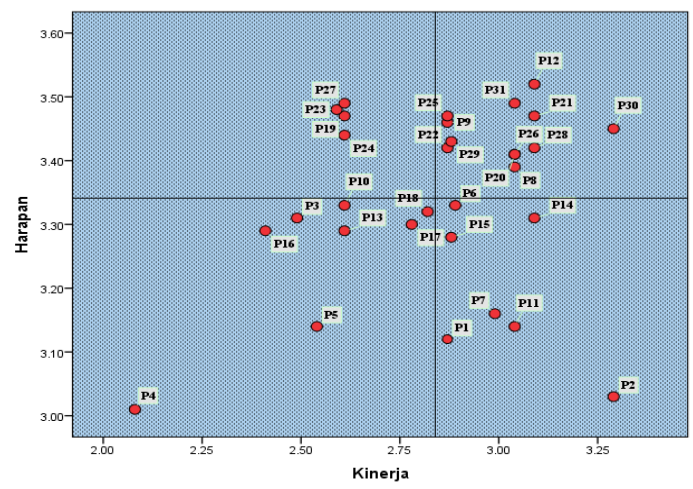

Gambar 4.8 Diagram Kartesius

Sumber: Data Olahan Peneliti (2018)

Berdasarkan pemetaan indikator pernyataan pada Gambar 4.8 dalam Diagram Kartesius diatas, maka penjabaran setiap kuadran adalah sebagai berikut:

1. Kuadran I Tingkatkan Kinerja

Pada kuadaran ini terdapat faktorfaktor yang dianggap penting dan atau diharapkan konsumen akan tetapi kinerja perusahaan dinilai belum memuaskan sehingga pihak perusahaan perlu berkonsentrasi untuk mengalokasikan sumber dayanya guna meningkatkan performa yang masuk pada kuadran ini, Adapaun indikator pernyataan yang termasuk ke dalam kuadran I adalah :

a. Pernyataan 19 yakni Karyawan bersikap sopan dan ramah kepada pelanggan

b. Pernyataan 23 yakni Kenyamanan pelanggan saat datang ke PT Ramajaya

c. Pernyataan 24 yakni Perusahaan melayani tanpa memandang latar belakang pelanggan

d. Pernyataan 27 yakni Perusahaan memberikan toleransi terhadap keterlambatan pembayaran kepada pelanggan

2. Kuadran II Pertahankan Kinerja

Pada kuadaran ini terdapat faktorfaktor yang dianggap penting dan diharapkan sebagai faktor penunjang kepuasan konsumen sudah sesuai sesuai dengan yang dirasakan sehingga perusahaan wajib untuk mempertahankan prestasi kinerja tersebut.
Adapaun indikator pernyataan yang termasuk ke dalam kuadran II adalah:

a. Pernyataan 8 yakni ketepatan karyawan dalam perbaikan mesin pelanggan

b. Pernyataan 9 yakni pelanggan diberikan kemudahan dalam melakukan transaksi pembayaran

c. Pernyataan 12 yakni pelayanan administrasi kepada pelanggan di PT Ramajaya Copier cepat dan mudah

d. Pernyataan 20 yakni terdapat jaminan ganti rugi terhadap kerusakan barang

e. Pernyataan 21 yakni karyawan menguasai mesin dan peralatan pendukung

f. Pernyataan 22 yakni terdapat jaminan keamanan dalam setiap transaksi yang dilakukan pelanggan dengan perusahaan

g. Pernyataan 25 yakni perusahaan konsisten dalam melayani pelanggan

h. Pernyataan 26 yakni perusahaan menjalin komunikasi yang baik kepada pelanggan

i. Pernyataan 28 yakni karyawan paham terhadap keluhan dan keinginan pelanggan

j. Pernyataan 29 yakni penggunaan seragam pada karyawan

k. Pernyataan 30 yakni karyawan menggunakan tanda pengenal

1. Pernyataan 31 yakni karyawan menjawab pertanyaan dari pelanggan dengan baik

3. Kuadran III Prioritas Rendah

Pada kuadaran ini terdapat faktorfaktor yang dianggap mempunyai tingkat persepsi atau kinerja aktual yang rendah dan tidak terlalu penting dan atau tidak terlalu diharapkan oleh konsumen sehingga perusahaan tidak perlu memprioritaskan atau memberikan perhatian lebih pada faktorfaktor tersebut. Adapaun indikator pernyataan yang termasuk ke dalam kuadran III adalah:

a. Pernyataan 3 yakni kebersihan perusahaan terjaga

b. Pernyataan 4 yakni perusahaan memiliki lokasi usaha yang strategis dan mudah dijangkau

c. Pernyataan 5 yakni perusahaan memiliki contact person yang jelas

d. Pernyataan 10 yakni perusahaan memiliki pencatatan yang akurat 
e. Pernyataan 13 yakni karyawan tanggap dalam membantu pelanggan

f. Pernyataan 16 yakni keryawan bersedia membantu pelanggan kapanpun dibutuhkan

g. Pernyataan 17 yakni karyawan menyampaikan informasi dengan jelas dan mudah dipahami kepada pelanggan

h. Pernyataan 18 yakni perusahaan cepat dalam menanggapi keluhan/complain dari pelanggan

\section{Kuadran IV Cinderung Berlebihan}

Pada kuadaran ini terdapat faktorfaktor yang dianggap tidak terlalu penting dan tidak terlalu diharapkan oleh pelanggan sehingga perusahaan lebih baik mengalokasikan sumber daya yang terkait pada faktor tersebut kepada faktor lain yang lebih memiliki tingkat prioritas lebih tinggi. Adapaun indikator pernyataan yang termasuk ke dalam kuadran IV adalah:

a. Pernyataan 1 yakni perusahaan memiliki fasilitas kantor dan permesinan penunjang pelayanan yang memadai

b. Pernyataan 2 yakni karyawan perusahan berpakaian rapi dan menarik saat memberikan pelayanan

c. Pernyataan 6 yakni tersedia layananan pengaduan bagi pelanggan

d. Pernyataan 7 yakni ketepatan perusahaan dalam pemenuhan janji kepada pelanggan

e. Pernyataan 11 yakni kemampuan melakukan implementasi strandar pelayanan secara tepat waktu

\section{KESIMPULAN}

Berdasarkan hasil penelitian yang dilakukan mengenai analisis kepuasan pelanggan terhadap kualitas pelayanan di PT Ramajaya Copier maka penulis menarik kesimpulan bahwa:

1. Dari 93 kuisioner yang penulis sebarkan kepada pelanggan PT Ramajaya Copier dengan karakteristik berdasarkan lokasi seluruhnya berada di Kota Batam berjumlah 93 responden dengan presentase $100 \%$. Karakteristik responden berdasarkan instansi responden yang berasal dari instansi swasta berjumlah 47 responden dengan persentase $50,5 \%$, instansi pemerintah 24 responden dengen persentase $25,8 \%$ dan dari intansi asing berjumlah 22 responden dengan persentase $23,7 \%$. Karakteristik responden berdasarkan lama kontrak yak responden yang memiliki kontrak kerja antara $3-6$ bulan berjumlah 33 responden dengan persentase $35,5 \%, 6-12$ bulan 50 responden dengan persentase $53,8 \%$ dan kontrak kerja yang lebih dari 1 (Satu) tahun berjumlah 10 reponden dengan persentase $10,8 \%$. Karakteristik yang terakhir adalah karakteristik responden berdasarkan bidang usaha yakni bidang usaha jasa berjumlah 50 responden dengan persentase $53,8 \%$, non jasa 33 responden dengan persentase $35,8 \%$ dan bidang usaha lainnya 10 responden dengan persentase $10,8 \%$.

2. Terdapat 4 indikator pelayanan yang merupakan fokus utama bagi perusahaan dalam melakukan perbaikan untuk meningkatkan kepuasan pelayanan bagi pelanggan, adalah:

a. Karyawan bersikap sopan dan ramah kepada pelanggan

b. Kenyamanan pelanggan saat datang ke PT Ramajaya Copier

c. Perusahaan melayani tanpa memandang latar belakang pelanggan

d. Perusahaan memberikan toleransi terhadap keterlambatan pembayaran kepada pelanggan

\section{Saran}

Berdasarkan pembahasan penelitian yantg telah penulis lakukan, maka penulis bermaksud mengajukan saran - saran sebagai pelengkap mengenai kepuasan pelanggan terhadap kualitas pelayanan di PT Ramajaya Copier yang termasuk kedalam 
fokus utama perbaikan kepuasan pelanggan adalah:

1. Sikap karyawan kepada pelanggan diharapkan untuk lebih ditingkatkan lagi dengan memberikan arahan, pemahaman, dan pelatihan kepada karyawan mengenai pelayanan terhadap pelanggan.

2. Sebaiknya perusahaan membuat ruang workshop terpisah dengan akses jalan utama yang dilalui oleh pelanggan yang berkunjung ke PT Ramajaya Copier dan juga penambahan karyawan khusus untuk di tempatkan sebagai cleaner agar kebersihan ruangan yang ada di PT Ramajaya lebih terjaga.

3. Sebaiknya perusahaan tidak memandang latar belakang pelanggan, dan membuat sistem antrian kepada pelanggan yang melapor kerusakan mesin sehingga perusahaan dapat mendahulukan pelanggan yang pertama melapor.

4. Sebaiknya perusahaan memberikan pengertian kepada pelanggan mengingat tempo yang diberikan sudah cukup panjang, perusahaan juga dapat mengingatkan tanggal penagihan yang jatuh tempo dari jauh hari berkala sehingga pelanggan dapat mempersiapkan pembayaran.

\section{Keterbatasan}

Dalam penelitian ini penulis merasa ada beberapa hambatan dalam melakukan penelitian. Adapun hambatan -hambatan yang dirasa penulis adalah :

1. Penelitian ini hanya berfokus di Kota Batam, tidak menjangkau kantor pusat yang berada di Kota Tanjungpinang.

2. Penelitian ini mengukur kualitas pelayanan hanya menggunakan metode Impotance Performance Analysis (IPA), tidak menggunakan dengan metode kualitas pelayanan yang lain seperti metode Servqual,

3. Penelitian ini hanya dilakukan selama 4 bulan, sehingga dirasa perlu waktu untuk menjangkau area keseluruhanya untuk memaksimalkan hasil penelitian berikutnya.

\section{DAFTAR PUSTAKA}

Adrianto, Muhammad. 2014. Analisis Adrianto, Muhammad. 2014. Analisis Kepuasan Konsumen. Jurnal Bisnis, Manajemen \& Perbankan. 1- (23384409). $102-120$.

Alma, Buchari. 2003. Manajemen Pemasaran dan Pemasaran Jasa. Edisi 2. Bandung: Alfabeta.

Arif Fadhillah, Muhammad. 2012. Analisis Kinerja Perusahaan Dilihat dari Kepuasan Pelanggan Pada Perusahaan Kontraktor Telekomunikasi dengan Menggunakan Pendekatan Metode B2B Servqual dan Impotance Performance Analysis (IPA). UI: Skripsi.

Azwar, A. 1996. Menjaga Mutu Pelayanan Kesehatan, Jakarta: Pustaka Sinar Harapan.

Greenberg, P. 2010. Manajemen Hubungan Pelanggan Sebagai Kecepatan Cahaya: Edisi Keempat. Mc GrawHill.

Hamari, Juho. 2017. Kualitas layanan menjelaskan mengapa orang menggunakan layanan freemium tetapi tidak jika mereka menjadi premium: Sebuah studi empiris dalam game free-to-play. Jurnal Internasional Manajemen Informasi. 37 (2017) 1449-1459

Khotler, Philip, 2000. Manajemen Pemasaran : Analisis, Perencanaan, Implemntasi dan Kontrol, terj : Hendra Teguh dan Ronny Antonius Rusly, Edisi 9, Jilid 1 dan 2, PT Prenhallindo, Jakarta

Khotler, Philip dan Kevin Lane Keller. 2007. Manajemen Pemasaran. Edisi Kedua Belas. Indeks: Jakarta

Oscar Ong, Jogan. 2014. Analisis Kepuasan Pelanggan dengan Importance Performance Analysis di SBU Laboratory Cibitung PT 
SUCOFINDO (PERSERO). IX (1).

1- 10. President University: Jurnal.

Purnomo, Wirdha. 2015. Analisa Kepuasan

Pelanggan Terhadap Bengkel dengan Metode IPA (Importance Performance Analysis) di PT. Arina Parama Jaya Gresik. 3 (3). 54-63. UNS: Jurnal.

Sugiyono. 2016. Metode Penelitian Manajemen. Dalam Sugiyono. Bandung: Afabeta, CV.

Sugiyono. (2014). Metode Penelitian Manajemen. Dalam Sugiyono. Bandung: Alfabeta, CV.

Thtersia Ifi Wilis. 2015. Analisis Kualitas Pelayanan Dengan Menggunakan Gap Analysis dan IPA Pada Restoran Fusion Food. UGM: Skripsi.

Tjiptono, Fandy, 2000, Strategi Pemasaran, Edisi-1, Yogyakarta, ANDI

Tjiptono, Fandy, 2002, Strategi Pemasaran, Edisi-2, Yogyakarta, ANDI

Tjiptono, Fandy, 2005, Pemasaran Jasa, Edisi-1, Banyumedia, Malang-Jakarta Timur

Yola, Melfa. 2013. Analisis Kepuasan Konsumen Terhadap Kualitas Pelayanan dan Harga Produk pada Supermarket. 12 - (2088-4842). 301 - 309. UIN: Jurnal

Thtersia Ifi Wilis. 2015. Analisis Kualitas Pelayanan Dengan Menggunakan Gap Analysis dan IPA Pada Restoran Fusion Food. UGM: Skripsi.

Tjiptono, Fandy, 2000, Strategi Pemasaran, Edisi-1, Yogyakarta, ANDI

Tjiptono, Fandy, 2002, Strategi Pemasaran, Edisi-2, Yogyakarta, ANDI

Tjiptono, Fandy, 2005, Pemasaran Jasa, Edisi-1, Banyumedia, Malang-Jakarta Timur

Yola, Melfa. 2013. Analisis Kepuasan Konsumen Terhadap Kualitas Pelayanan dan Harga Produk pada Supermarket dengan Menggunakan Metode Importance Performance Analysis (IPA). 12 - (2088-4842). 301 - 309. UIN: JurnalZeithaml et al., 1996. Measuring the quality of relationship in pelanggan service: An empirical study. European. Journal of Marketing Zeithaml et al., 1996. Measuring the quality of relationship in pelanggan service: An empirical study. European. Journal of Marketing Zeithaml et al., 1996. Measuring the quality of relationship in pelanggan service: An empirical study. European. Journal of MarketingZeithaml, Valarie A., And Mary Jo Bitner. (2000). Service Marketing: Integrating Pelanggan Focus Across The Firm, Second Edition. New York, NJ: Mc GrawHill Companies Inc.

Zeithaml, Valarie A., and Mary Jo Bitner. (2000). Service Marketing: Integrating Pelanggan Focus Across The Firm, Second Edition. New York, NJ: Mc Graw-Hill Companies Inc.

Zeithaml et al., 1996. Measuring the quality of relationship in pelanggan service: An empirical study. European. Journal of Marketing

Zeithaml, Valarie A., And Mary Jo Bitner. (2000). Service Marketing: Integrating Pelanggan Focus Across The Firm, Second Edition. New York, NJ: Mc Graw-Hill Companies Inc. 